\title{
Evaluating School Improvement Efforts - Pupils as Silent Result Suppliers, or Audible Improvement Resources?
}

\author{
Carl-Henrik Adolfsson \\ Linnaeus University, Sweden \\ Jan Håkansson \\ Linnaeus University, Sweden
}

\begin{abstract}
This article contributes to a perspective of school development, where pupils' experiences of the teaching they encounter are regarded as a result of improvement work. In a three-year research collaboration with four nine-year compulsory schools in a large Swedish municipality, researchers have continuously conducted group interviews with different actors, collected relevant documentation and reported their preliminary analyses to the schools. In the light of previous research, the results show that the development areas that have been in focus in the schools have in some cases had an impact on the teaching. However, no homogenous change is evident. Rather, the variation between classrooms, teachers and subjects is great, especially if the pupils' perspectives are taken into consideration. The pupils' experiences and voices on how the improvement work materialises in the classroom contribute to explaining the connections, or lack of them, between the school and classroom levels.
\end{abstract}

Keywords: school improvement; teaching; evaluation; pupils voice; learning experiences.

\section{Introduction}

Although much has happened within research on reform initiatives, school effectiveness and school improvements, especially concerning actors such as principals and teachers, the question of pupils' positions and importance in school improvement work remains unanswered. In this paper pupils' learning experiences of the teaching they encounter are regarded as a result of the school's improvement work. The starting point for the case that is presented and analysed here is a three-year research collaboration with four nine-year compulsory schools in a large Swedish municipality. The four schools (preschool class-Year 9) are described as focus schools, are situated in multicultural and 
vulnerable areas and have relatively low academic results. Over a three-year period researchers have continuously conducted group interviews with different actors (pupils, teachers and principals), collected relevant documentation on academic results and improvement work, and reported the preliminary analyses to the schools. Pupils' participation and involvement in attempts to improve schools and their academic results can be regarded as a reasonable prerequisite for success. Even though some research on pupils' perspectives has been conducted in the field (cf. Keddie, 2015; Scanlon, 2012), research on school improvement with a clear pupil perspective is relatively limited. We of course acknowledge that pupils' examination results and grades are also important indicators of success in school development; although our ambition in this context is to extend the frames of reference for how the outcome of the development work can be traced in a more advanced way. This article therefore has a particular focus on how, in the analyses of the result of schools' development work, a pupil perspective can contribute to the understanding of the school improvement outcome. The question is how pupils' experiences and learning about the school's and the teachers' attempts to develop the teaching and support pupils' development can constitute a source that shows what is possible to change and also which learning identities the pupils are able to develop. The overarching purpose of the article is accordingly to contribute to the understanding of different content and learning results in school improvement work on the basis of the following two questions:

1) What does the outcome of school improvement work in the classroom look like from the pupils' perspectives?

2) How can pupils' experiences be used as a way of evaluating school improvement work?

The purpose is therefore partly empirical and partly practical/methodological. There is also an ambition to highlight the reciprocity between research and practice, where the cases that are examined and analysed can contribute to shedding light on the merits, challenges and implications in the work of allowing pupils' voices to be part of the outcome of the improvement work.

\section{Background to the study - research on change, effectiveness and improvement in schools}

Internationally, but also in Sweden, intensive discussions have taken place in recent decades about how pupils' academic results and schools' results can be improved. Major reforms in combination with different ways of measuring pupils' knowledge levels have been introduced in different parts of the world without appreciably influencing the results, largely due to changes in structural aspects, such as decentralisation, competition, school inspection and budgetary responsibilities (cf. Hopkins, 2016; Levin, 2008). At the same time, the reform agendas have often required a local school improvement work that is based on contextual relations and needs, which for example in Sweden is thought to have led to an increased interest in classroom-linked school development strategies, where teachers' and principals' learning is in focus, with the aim of developing the teaching and improving pupils' results (cf. Håkansson, 2015a). The Swedish National Agency for Education, has also in recent years introduced a school development programme with the aim of improving teaching and pupils' performances in specific subject domains, e.g. within what is called the 
mathematics booster'and 'the literacy booster', where teachers together, and under supervision, work with different content modules that include both theory and practical exercises.

Overarching analyses of the field emphasise the need to balance and integrate change at different levels in the education system (e.g., the classroom, school and system) and also to manage and balance external demands and ideas in combination with internal needs and prerequisites (cf. Adolfsson \& Alvunger, 2017; Chapman, Muijs, Reynolds, Sammons, \& Teddlie, 2016; Hopkins, Stringfield, Harris, Stoll \& Mackay, 2014). Recent research has also discussed how such overarching principles and strategies for school development can be combined with consistent research results on which aspects of teachers' actions in the classroom interact with pupils' learning and results (cf. Creemers \& Kyriakides, 2012; 2016; Håkansson, 2015b; Muijs, Kyriakides, van der Werf, Creemers, Timperley \& Earl, 2014). In both research and practice, descriptions of strategies for school development and the building up of schools' development capacities have been characterised in both research and practice by a strong focus on teachers' and principals' professional learning and development, which in turn has been expected to contribute to the change and improvement of teaching and pupils' learning (cf. Day, 2012). In neighbouring research fields, the concept of capital is used to understand how teachers' individual capabilities are part of a bigger picture that includes individual and collective learning, as well as other pedagogical resources such as different actors' approaches, engagement and attitudes to school development work (Hargreaves, 2001; see also Shulman \& Shulman, 2004). However, the question of how the results of different school improvement efforts should be evaluated at pupil level seems to be an area in which research needs to take a new step forward. For example, Reynolds, Teddlie, Chapman and Stringfield (2016) write that:

\footnotetext{
"The use of more specific measures of the educational environments inhabited by students could be a further step along the road towards 'student specific' school factors, whereby students as individuals accrue educational experiences that are measured and tagged to them individually, permitting a much fairer test of the 'educational factors' ..." (p. 97).
}

In this context, the researchers also draw attention to the need to examine the links between the classroom and school levels. In general, the research takes a school level perspective, while to a large extent pupils' experiences are connected to different niches of a school, depending on which subject they are taught in, which teachers they meet and which peer groups they are in (Reynolds et al., 2016). There is of course also research that weighs in different aspects connected to pupils' learning experiences and that gives voice to firsthand information about the teaching and learning environments that the pupils are exposed to and that could potentially contribute to development (see e.g., Ferguson, Hanreddy \& Draxton, 2011; Keddie, 2015; Scanlon, 2012). Other research has also examined how teachers interact and cooperate with pupils in the teaching in connection with development work (Wennergren \& Blossing, 2015). The ambition of this article is to contribute to a perspective of school 
development in which pupils' experiences of the teaching they encounter are also regarded as a result of improvement work.

\section{Outcome of school improvement, with a focus on pupils' results and teachers' learning}

The last decade has been characterised by a strong emphasis on influencing and improving students' performances by means of reforms and school improvement work, but also by attempts to make use of the potential in regional and local governance and the management of school development. As the research in the field shows, there is also an interest in studying the development and professional learning qualities and networks between schools, and a continued and increased emphasis on leadership with a connection to the quality of teaching and improvements in all pupils' academic performances (cf. Hopkins et al., 2014; Stoll, Bolam, McMahon, Wallace \& Thomas, 2006; Hallinger \& Heck, 2010; Lomos, Hofman \& Bosker, 2011). In general, this study links to the extensive research in the school improvement field, and in other contexts (Adolfsson \& Håkansson, 2018) we have used theoretical concepts (learning capital) in order to understand how principals' and teachers' individual capacities are included in the greater whole that comprises the individual and the collective learning (cf. Hargreaves, 2001; see also Shulman \& Shulman, 2004).

However, we understand that for the pupils, the outcome of the different efforts to improve the school and the teaching in general stops at standardised measurements of performance, for example international knowledge tests, national tests or accumulated grades, so-called merit rating. Non-cognitive or emotional aspects therefore tend to be marginalised in descriptions and analyses within the school improvement field. At the same time, the methods for following up this kind of goal are relatively undeveloped, both in research and in the school's systematic quality work. However, in effectiveness research a number of attempts have been made and some mutual relations (at an individual level) found between non-cognitive and cognitive abilities (Sammons, Davis \& Gray, 2016). In this article the focus is on pupils' learning experiences, for example in the form of motivation, confidence in their own ability to learn, and attitudes to the school and the teaching as central results of the school's improvement work. Seeing these learning experiences as results of the school's teaching can be significant in analyses of schools'improvement work. According to research, some of the pupils' subjective experiences and feelings connected to the school's activities interplay to some degree with how well the pupils achieve different educational goals (cf. Hattie, 2009; Hattie \& Anderman, 2013). But they can also provide important first-hand information about the impact that schools' improvement strategies have had in the classroom. However, we see few examples of such information being used to study the consequences of school improvement work. In the following section, we therefore refer to a selection of studies that highlight pupils' experiences and voices in the school improvement work as a basis for our analyses. 


\section{Outcome of school improvement - pupils' voices in the school improvement work}

Allowing pupils to voice their opinions in the school's change and improvement work and listening to their voices has been on the agenda in several school systems throughout the world for a long time. Several reasons as to why this can be significant are provided in research, for example that it can be seen as a right (the democratic incentive), that pupils acquire important personal, social and civic knowledge (the learning incentive) and that pupils' participation can contribute to better decision making and sustainable change (the participation incentive) (Thomson, 2010). In this research, there are also a number of different approaches to and studies of how pupils' voices are heard, such as pupils' feedback on the teaching and teachers' work (Keddie, 2015), pupils' views of structural and pedagogical changes (Scanlon, 2012), pupils' decision-making (Schratz \& Blossing, 2005; Lodge, 2005; Ferguson et al., 2011) and theories on student voice in school (Robinson \& Taylor, 2007).

The study as a whole focus on the school level, with overarching aspects of the professional learning of different actors and at different levels in improvement work. In contrast, this particular article examines how pupils' voices can function as indicators of whether the school's ambitions to change and improve the teaching actually reach the classroom. The pupil perspective in this study does not therefore represent research that directly builds on a political tradition of student voice, but instead draws attention to the pupils' "pedagogical voices", with a focus on their experiences in the classroom, how they are taught in the various subjects and how learning identities are formed in relation to the school's improvement work. There are several examples in research of more or less successful attempts to involve pupils in change and improvement work. For example Scanlon (2012) discusses the pupils' disappointment at not having been consulted about changes in things like final examinations, the length of each lesson and group compositions in an Australian comprehensive school. Even though the initiative for change was mainly externally motivated, the school also envisaged that the changes would contribute to pupils' increased involvement and attendance at school. However, the pupils came into the change process late and never "owned" the changes, even though according to the study's conclusions they made valuable contributions about both the good and less good qualities in the teaching. According to Scanlon (2012), the teachers were ruled by the test culture and thought that the pupils were much too immature to be consulted about teaching issues. With reference to such attitudes, the school was said to be characterised by an "ideology of immaturity" and therefore could not be described as a "listening school" (Scanlon, 2012).

On the other hand, in an English school improvement project, several positive consequences of an initiative linked to qualities in teaching and learning were reported (Quality in Teaching and Learning, QTL, Keddie, 2015). The aim here was to develop pupils' understanding and appreciation of teachers, teaching and learning processes, but also to support the pupils' relations with the teachers in order to improve the pedagogy and the relations, and to develop the pupils' self-images as learning individuals. At a more overarching level, it is 
emphasised that these goals are important in order to avoid pupils being overlooked in school development and to challenge the traditional distribution of power between teachers and pupils and the tight and restrictive measurement methods used in the school improvement work. After some training, the pupils in Year 8 functioned as observers of the teaching and gave feedback to the teachers, which according to Keddie (2015) clearly contributed to the work on improving the teaching. The pupils drew attention to and strengthened aspects of the teaching quality that were central to the learning process, for example high expectations, intellectual challenge and supporting teacher-pupils relations. However, Keddie (2015) stresses that the majority of student voice initiatives have their problems and flipsides, e.g. that schools mostly work with these issues for the sake of appearance, or that some pupils'voices are heard but not others. The teacher-pupil relation is also basically asymmetrical, and neither the pupils' nor the teachers' perspectives on teaching and learning processes are unproblematic, insightful or emancipating. One conclusion that was drawn was that the initiative was characterised by three important components: authenticity (taking pupils' points of view seriously), inclusion (incorporating marginalised voices) and power (fostering a feeling of cooperation between teachers and pupils and mutual respect) (Keddie, 2015).

The study that is presented in this article has certain points of contact with the above mentioned study, namely that pupils are regarded as important first-hand sources in school improvement work relating to classroom processes and the development of learning identities. An important difference, which will be touched on at the end of the article, is that we researchers acted as middlemen and interpreters of the pupils' statements about qualities in the teaching in order to then give regular feedback to the teachers and principals. A theme that would otherwise seem to reflect the recent decade's research on school improvementstudent voice is that the context that surrounds such research is about the increasingly strong emphasis on the demand for improvements in the pupils' academic results, primarily in certain subject areas such as mathematics, literacy and science. Our study also takes its point of departure in a similar frame of reference, where Swedish principals and teachers are under increasing pressure to pilot their pupils to achieving the minimum requirements for entry to a professional programme at upper secondary school, which means that the pupils must have pass grades in a least eight of the secondary school's 17 subjects. By examining this kind of school environment with complementary and alternative result measurements, and as a sub-element involving the pupils via their direct experiences of the teaching, we have been able to get closer to and try to understand what Keddie (2015) calls a "... rich and intelligent form of teacher accountability ...". Without disregarding the significance of measuring pupils' study achievements, the objective here is to contribute to a more nuanced and profound picture of school improvement work in practice.

\section{The case}

According to the Education Act, systematic quality work is compulsory for schools and responsible authorities in the Swedish education system. Local quality work involves several steps of data collection, documentation and selfassessment, with the aim of contributing to professional development and better 
quality. Alongside the demand for local improvement work, there is also a national inspection and compulsory national tests for Years 3, 6 and 9 at the nine-year compulsory school level. Grades are given from Year 6 in all subjects. The research was conducted in connection with the ongoing improvement work in four nine-year compulsory schools (preschool class-Year 9, F-9) situated in multicultural and vulnerable areas and with relatively low academic results. All the four schools are substantially over (between 240 and 421) the average value (100) of the socioeconomic index that the municipality uses for to distribute resources equally to the schools. As part of the systematic quality work, the schools were included in a number of the municipality's education department's activities over a three-year period, e.g. support for result analyses, lesson observations with coaching, collaborations with other schools and with social agencies. At the same time, the local development work in the schools was carried out in accordance with the needs that had been identified, most of which were directed towards developing the pupils' basic competencies, such as mathematics, literacy and language development in all subjects. The quality aspects of the teaching that were focused on were for example learning assessments and clarity around goals and knowledge requirements. A good study climate, homogeneous structure, organisation of the teaching and leadership in the classroom was also highlighted in the development work.

\section{Method and data}

The part of the research project that is accounted for in this article mainly has a qualitative and interpretive approach, i.e. it is oriented towards the actors' understanding and experiences of the improvement work that is carried out at the schools, with a specific focus on the pupils' learning experiences (cf. Cohen, Manion \& Morrison, 2000). Summaries and analyses of pupils' academic achievements in the form of national tests and grades have also been made but are not in focus here. Over a three-year period, researchers have continuously conducted group interviews with different actors (pupils, teachers and principals), collected the relevant documentation on academic results and improvement work, and fed preliminary analyses back to the schools. Three specific aspects of school improvement and change over time in relation to these aspects have been in focus in the interviews:

- The school's focus, strategies, organisation and leadership in the improvement work.

- The teaching practices (e.g. teaching patterns, assessment practices).

- Pupils' motivation and self-confidence (pupils' perceptions of their own abilities and the school's support of them).

Some 60 semi-structured interviews (40-60 minutes) were conducted during the three years with groups of principals $(n=16)$, teachers $(n=40)$ and pupils from Years 6-9 $(n=80)$. The interviews were conducted during the same period each year with the same participants from the respective schools, i.e. every group was interviewed three times in total. The interviewees were informed about the purpose of the interviews, how the data would be managed and that they could end their participation at any time. All the interviewees, including the pupils' guardians, gave their permission to participate. The study has thus followed the 
ethical guidelines for research within the field and the requirements for participation, information, consent and confidentiality (cf. HSFR, 2002). All the interviews were transcribed, continually analysed and discussed with representatives from the involved schools and with the local education authority. At all the interviews in years two and three, the researchers' preliminary analyses and interpretations constituted the basis for the formation of interview guides. To a certain extent, the discussion also served as participant validation of what had emerged in the preceding interview (cf. Bryman, 2002). In the final year, the analyses focused on identifying eventual changes in relation to the above three aspects of school improvement. In focus for this article is the potential in the pupils' contributions to the nuancing of different kinds of outcome in the school improvement work.

\section{Results}

When the qualitative and empirical material from the four schools' ongoing improvement work was processed and analysed at the end of the three-year period, it became clear that the work that had been initiated three-four years earlier was still largely in place. The focus revolves around general quality aspects of the teaching, such as assessment, language development, leadership in the classroom and homogeneous organisational structures, but also more specifically linked to mathematics teaching (the mathematics booster) and the development of pupils' language and literacy competences (the literacy booster). From all the four schools, consequences emerge in the form of learning and change that can be linked to the past and present development work. According to principals and teachers, there are signs of change in the classroom, for example in the shape of a different assessment practice with clearer goals, assessment matrices, varied examination forms and feedback. There are also signs of language development or language support work being carried out, where teachers to a greater extent than before explain words and concepts for the pupils. At the same time, the general picture of school improvement work is nuanced by how the pupils in the interviews describe the changed teaching patterns, assessment practices and support for motivation and self-confidence.

\section{The pupils' depictions of changed teaching patterns}

In the final set of interviews when the pupils talk about the different aspects of the teaching they encounter and how they perceive the school's support for motivation and their own ability to learn, there are many similarities with that which emerged in the first two sets of interviews. In the four schools, there are examples of how the improvement work is realised in the classroom, although from the pupils' perspective, the impact and extent varies between teachers, subjects and lessons. However, from the pupils' perspective, changes in the teaching patterns are difficult to detect, especially due to the staff changes that occurred in Years 6 to 9. At the same time, the pupils note that there have been changes in the structure and forms of the teaching. In one of the schools, the mathematics teaching has been reorganised into more and smaller groups, and there are also changes in direction in terms of more teacher briefings, dialogue and discussions about how to solve problems: 
"We have more briefings and everyone thinks this is good. I understand more then" (Pupil 1).

In another school, the pupils in Year 9 discuss how the beginning and end of lessons that the teachers have worked to develop appear from their perspectives:

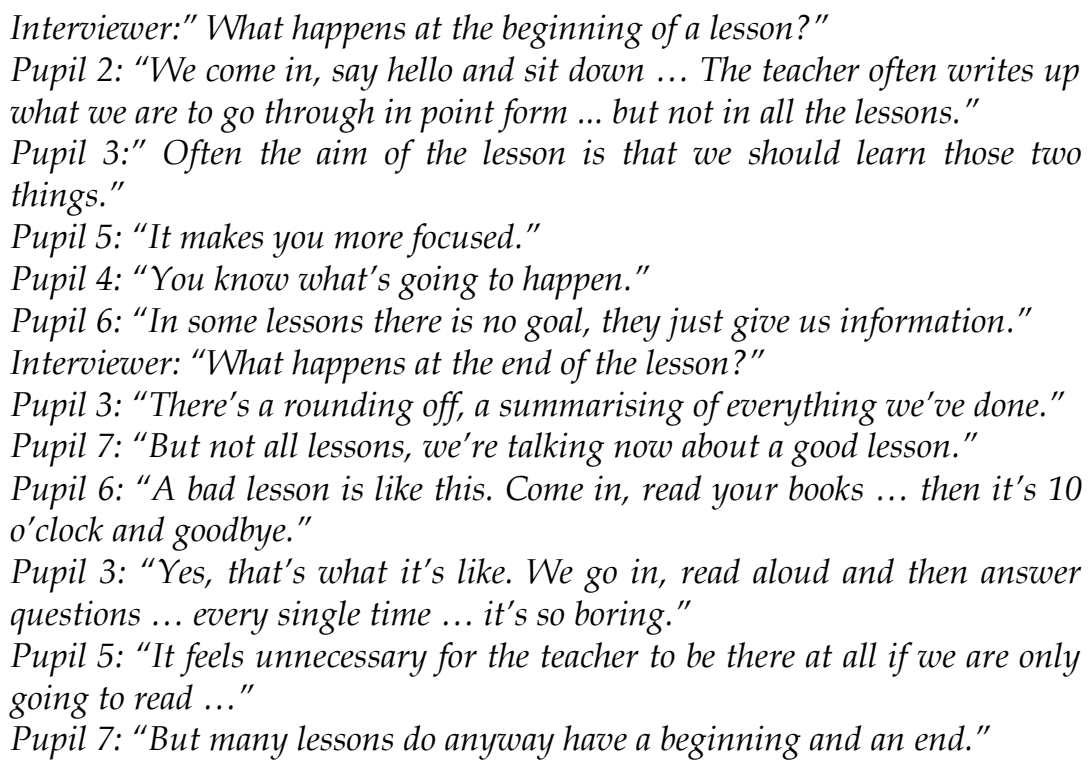

What the pupils have conveyed during the three years of the ongoing research is that certain "teaching routines" that have been tested in the schools have contributed to a greater homogeneity and clarity. At the same time, the changes do not embrace all the teaching at the school. It could also be the case that homogeneous patterns in the teaching that are generally understood by the pupils as positive have their limitations. The pupils can have different preferences for which kind of teaching they think benefits their learning, and teachers can also function in different ways in different teaching situations, e.g. due to emergency occurrences, or that the situation needs to be dealt with in a particular way. According to the pupils, the intensity of the teaching strategies that have been tested wanes towards the end of a term or academic year. At one of the schools, the teachers started the academic year by explaining the lesson goals, but this then tailed off as the year progressed:

"It was like that in all the lessons before. Then it was sometimes, but then it stopped ..." (Pupil 8).

\section{The pupils' depictions of changed assessment practices}

The part of the teaching practice that is generally thought to have changed in all the schools is assessment in its broadest sense, e.g. in questions relating to the clarity of goals and knowledge requirements, assessment matrices and feedback:

"Some teachers have put a lot of energy into giving feedback and good assignments so that we will be able to really show what we can do" (Pupil 9). 
During the three-year period, the use of so-called assessment matrices has been developed in the schools, which the pupils are generally positive to. However, the pupils point out that these are more prevalent in theoretical subjects, such as Swedish, mathematics and science, and less so in practical aesthetic subjects like music and art. The amount of detail given in the matrices for the goals and performance criteria means that the pupils can find it difficult to achieve all the knowledge requirements:

"It feels tough when you've managed almost everything, but there's something that lowers your grade" (Pupil 10).

According to the pupils, the part of the assessment practice that appears to be relatively unchanged in the schools during the three-year period is the examination form. The picture that is painted by the pupils thus clashes with the principals' and teachers' statements that the examinations are now more varied. According to the pupils, the most common assessment and grading methods are tests that are carried out during the lessons and different kinds of submitted assignments. Oral tests, presentations and short diagnoses also occur, although not to the same extent. The differences between teachers are also significant, where some teachers focus more on large-scale tests, whereas others create more and shorter examinations. The pupils' uncertainties around how much of what they demonstrate in the lessons means, or how it is evaluated, remain the same during the research period.

\section{The pupils' depictions of support for motivation and self-confidence}

With regard to the schools' support for pupils' motivation and self-confidence, the overall picture after the three sets of interviews is that the schools contribute in several ways to the pupils' learning experiences. At the same time, this is a sensitive area, where especially the teachers look for a balance between encouraging and supporting the pupils on the one hand, and demanding achievements and exertion on the other. The driving forces for the pupils to learn things and perform vary considerably, although a strong factor that has been highlighted by the pupils during the research period is the teachers' expectations and support:

"When the teachers help with a new strategy ... and they say that now you can continue with it ... and you realise that you've succeeded with it ..." (Pupil 11).

"Just people who care, engaged teachers" (Pupil 12).

The demand for pupils to perform and demonstrate their knowledge also increases at the end of the term when it is time to set grades. According to the pupils, even if it is difficult to be examined at the beginning of a term or study area, there is a need for planning in order to avoid an accumulation of tests at the end of the term or academic year. The following dialogue between some of the pupils in one of the interview groups highlights this particular problem: 
Pupil 13: "It's not possible to have tests at the beginning of term, because you haven't learned anything then. At the end there are tests in everything, so there's a lot all at once."

Pupil 14: "But they could anyway plan things better."

Pupil 13: "What can you have tests before you've learned anything?"

Pupil 14: "But they could put small short tests in-between and not have a big test at the end, you anyway forget things ... you'd think that the teachers should know that we pupils want to do our best ... in that case it's easier when you've just gone through something."

In our interview material, there are also examples of pupils who do not think they have been treated in a way that supports their motivation or gives them strength to try to improve their results. There are also examples of the reverse:

Pupil 15: "If I say that I want an A, they laugh a little ... you can always dream ... it doesn't feel as though they believe the pupils that they can do better."

Pupil 16: "In some subjects they can support you if the tests don't go well." Pupil 17: "But sometimes I think that I have to demonstrate that I am capable of a higher grade. It can also be an incentive that teachers don't really believe that you can do it."

Pupil 18: "I would be more motivated if they said that we could do this together."

Pupil 19: "Yes, if they laugh I wouldn't be motivated."

Pupil 20: "If you've done lots of assignments well and worked hard in the lessons, but if the test didn't go so well, the teacher could ask you what went wrong. I know that you can do it, but why didn't you show it? They ask you how you are and you can tell them."

The task of supporting the pupils' learning in a credible and stimulating way is both complex and sensitive. Even though the overall pattern from our interviews at the schools is that the teachers try hard to respond to the pupils by balancing support and demands, it can be perceived in different ways by different individuals. According to some of the pupils' statements, they do not always get the response they expect when they want to improve (and get a higher grade). This in turn could be because some teachers do not believe that (some) pupils are capable of improving their grades, but also that the teachers see that the time for reaching the desired grade level is too short. The pupils have thus (according to the teachers) "overestimated" their chances of improving their grades.

Taking all these factors into account, the pupils' voices on the schools' ongoing improvement work contribute to both endorsing and contradicting the principals' and teachers' descriptions. The following discussion section analyses how this in turn can contribute to more nuanced perspectives on the outcome of school improvement work, and how pupils' perspectives can result in more realistic expectations of what is possible to achieve.

\section{Discussion}

After a brief introduction to the general interpretations from the project, the discussion focuses on what the pedagogic outcomes of the school improvement 
work in the classroom look like from the pupils' perspectives, as well as how the pupils' experiences can be used to evaluate this work. Based on our overarching analyses of the schools' improvement work, it seems that the primary aim has been to train the teachers in different areas, for example in linguistic development working methods, teachers' leadership, formative assessment, the didactics of mathematics ... etc. However, several activities seem to have been difficult to incorporate into the teaching, i.e. the transformation from teachers' learning to practical teaching proved to be a more complicated process than the schools have envisioned, with the possible exception of the development work around mathematics teaching and some of the work around formative assessment. At the same time, this is not in any way a new phenomenon. For example, Antoniou and Kyriakides (2011) showed in an experimental study that even if teachers know how to teach effectively, it does not always influence how they conduct their teaching in real situations. The importance of facilitating such a process by means of practical elements in the improvement work is emphasised by the researchers. The pupils' statements in our interview material about the teaching they receive indicates that the development areas in focus at the schools have in some cases had an impact on the teaching. However, no homogeneous picture of change has emerged, but rather that the variation between classrooms, teachers and subjects is huge. The pupils' experiences and voices of how the improvement work has been realised in the classroom contribute to a large extent to explaining the connections, or lack of connections, between the school level and the classroom level - something that researchers have reported as a necessity within the school improvement field (cf. Reynolds et al., 2016).

Another kind of outcome of the improvement work that the pupils have contributed to making visible is the difficulty of maintaining the changes that have been initiated over time and not "relapsing" into the teaching that was conducted earlier. The "transformation problem" from learning to the practical teaching described above could be one reason for this, although the picture given by the pupils also shows a differentiation in the pupils' perceptions of what is a change for the better and vice versa. The realisation of long-term and lasting changes in the teaching will presumably require the pupils (and the teachers) to understand that they will benefit from the changed practices. This could mean very different time perspectives for the development work in different classrooms and in different schools, where both teachers and pupils will need to develop an "ownership" in relation to the ongoing work (cf. Scanlon, 2012). However, at one of the schools the improvement work was characterised by such a direction, i.e. it was particularly there the transmission of students' experiences resulted in discernible changes in classroom practice. At the same school there was also a balance between a "top-down" and "bottomup"- oriented governance and an interest in listening to the pupils, which in turn increased the legitimacy of the development work that was carried out (Hopkins et al., 2014; Chapman et al., 2016; Scanlon, 2012).

The pupils' learning experiences in terms of motivation and a belief in their own abilities are, especially in Year 9, characterised by the school's result orientation 
and the pursuit of grades that are sufficient for continued studies at upper secondary school level. At the same time, the empirical material from the interviews with the pupils shows that, in general, the teachers are good at simultaneously managing and meeting the pupils' emotional and cognitive needs, even if certain aspects are thought to be harder than others. This for example relates to the question of how the teachers' expectations of behaviour and achievements meet the pupils' expectations of themselves and of the teachers' possibilities to support the pupils in their development. A "calibration" like this involves a balancing act for the teachers, in that on the one hand generally high expectations do not work for all pupils, and on the other hand the pupils' expectations of what is possible to achieve in a short time do not correspond with the teachers' expectations of what each pupil is capable of. Nonetheless, our impression is that the research efforts to include pupils' voices and experiences as outcomes of the schools' improvement work to some extent contributed to the creation of authenticity, inclusion and mutual respect between teachers and pupils (cf. Keddie, 2015). In our interpretation this was the implication of the message from school leaders and teachers when they responded to the researchers' preliminary analyses during the three years, as well as from the pupils when meeting them regularly.

In most of the school development work the pupils emerge as the most important target group, albeit in different ways. In general, it is about a focus on improving students' results in relation to some kind of quantitative measurement. The pupils' experiences of their schooling, in terms of different learning experiences linked to teaching, assessment, motivation ... etc., are often dealt with sporadically in both research and in the actual development work. In this project, the purpose has been to make the pupils' perspectives on some selected aspects of teaching, learning, motivation and self-confidence visible the areas that the pupils have first-hand information about and which in the research in the schools that we have collaborated with have stood out as significant for school improvement. When this kind of material is linked to principals' and teachers' perspectives on the school's organisation of the systematic quality work, teaching and learning, school improvement can be understood in a more nuanced way. What is learned is that the pupils' depictions are essential for an understanding of the success of school development. If the point of departure is that it is the pupils' needs - based on where they are in their learning - that constitute the starting point for all school development (cf. Parr \& Timperley, 2010; Timperley, Parr \& Bertanees, 2009; Timperley, 2011), we find that a large part of what the four schools' have worked on links to what the pupils also express in the interviews that have been conducted. Much of that which has been done in connection with the development work in mathematics and literacy teaching and different aspects of the teaching, e.g. leadership in the classroom, clearer goals, assessment ... etc., has also been appreciated by (the majority of) the pupils. At the same time, based on what has been identified as the teachers' needs, the development work has not been able to be carried out consistently and sustainably. The pupils' statements show that the schools have different strengths and weaknesses in 
relation to the selected improvement areas, which means that the pupils' needs have not been fully met in the development work.

\section{Conclusion}

One conclusion is that there is a potential in developing and broadening the pupils' participation in the school's improvement work. The three-year collaboration with the schools has contributed to amplifying the pupils' voices, which in turn has contributed to and influenced all the phases of the school development work. In schools located in especially challenging contexts (cf. socioeconomic index), the quality of the teaching can constitute a key factor in improving the results and make a difference for the pupils' possibilities to achieve the educational goals and acquire important learning experiences for the future. However, studies in schools facing extreme challenges show the necessity of a number of parallel strategies in addition to a focus on pupils' basic abilities, the classroom level and best practice, e.g. organisational coordination; cultural changes and the use of qualitative as well as quantitative data (cf. Reynolds, Harris, Clarke, Harris \& James, 2006). The pupils' learning experiences could thus be the missing link in the school improvement work. The four schools that have been studied here do not seem to have fully reached that which Keddie (2015) describes as a "... rich and intelligent form of teacher accountability ..." This requires more systematic feedback routines where the pupils are made visible over time, not just through their study performances, but also through the important experiences they accumulate as bearers of firsthand information about how the teaching works and about what kind of support they receive in terms of motivation and confidence in their own abilities to cope with school (cf. Reynolds et al., 2016).

In this study, we researchers have functioned as mediating links between the pupils on the one hand and principals and teachers on the other, which differs from what is reported in Keddie's (2015) study, where the pupils were trained as observers of the quality of the teaching and were expected themselves to give feedback to the teachers. This is one possible limitation of the chosen strategy here. The effects of the pupils' feedback are probably stronger when it is given directly to the teachers, although in hindsight our judgement is that the prerequisites for carrying out such a strategy in the actual schools would have been limited. Giving a unified analysis and feedback of the pupils' interviews to the principals and teachers at the four schools was a step on the way to showing the potential of allowing the pupils to have a say in the improvement work, with the advantage that the researchers could give legitimacy to the pupils' perspectives in relation to the schools' activities and efforts. However, our conclusion is that the feedback strongly contributed to a nuancing of the schools' self-images around the consequences of the development work, which was confirmed by principals and teachers; something that in the long-term could also strengthen the desire to work more persistently with improvements that actually reach the classroom. This study has shown that pupils' role in the improvement work can over ride that of simply being silent result suppliers. The pupils' potential of also functioning as audible improvement resources has proved to be significant. 


\section{Limitations and future research}

The limited number of cases of course limits the scope of this study. However, one important experience for future research is the importance of continued investigation in "student-specific school factors" (Reynolds, et al., 2016). Qualitative evaluation of the links between the classroom and school levels through pupils' learning experiences might have the potential to complement and deepen our understanding of school improvement results measured by quantitative outcomes.

\section{References}

Adolfsson, C-H., \& Håkansson, J. (2018). Evaluating School Improvement by Learning Capitals. Improving Schools, (online 28 June 2018). doi.org/10.1177/1365480218784039

Adolfsson, C-H., \& Håkansson, J. (2016). Learning compulsory schools. Linnaeus University: Unpublished final report.

Adolfsson, C-H., \& Alvunger, D. (2017). The nested systems of local school development: Understanding improved interaction and capacities in the different sub-systems of schools. Improving Schools, 20(3), 195-208. doi.org/10.1177/1365480217710874

Antoniou, P., \& Kyriakides, L. K. (2011). The impact of a dynamic approach to professional development on teacher instruction and student learning: Results from an experimental study. School Effectiveness and School Improvement, 22(3), 291-311. doi.org/10.1080/09243453.2011.577078

Bryman, A (2002) Samhällsvetenskapliga metoder. [Social Research Methods]. Stockholm: Liber (in Swedish).

Chapman, C., Muijs, D., Reynolds, D., Sammons, P., \& Teddlie, C. (Eds.) (2016). The Routledge International Handbook of Educational Effectiveness and Improvement. London and New York: Routledge. doi.org/10.4324/9781315679488

Cohen, L., Manion L., \& Morrison, K. (2000) Research Methods in Education. 5 ed. London: Routledge.

Creemers, B. P. M., \& Kyriakides, L. (2012). Improving quality in education: dynamic approaches to school improvement. Abingdon, Oxon: Routledge. doi.org/10.4324/9780203817537

Creemers, B. P. M., \& Kyriakides, L. (2016). Theory development in educational effectiveness research. In Chapman, C., Muijs, D., Reynolds, D., Sammons, P., \& Teddlie, C. (Eds.). The Routledge International Handbook of Educational Effectiveness and Improvement. London and New York: Routledge. doi.org/10.4324/9781315679488

Day, C. (Ed.) (2012). The Routledge international handbook of teacher and school development. London: Routledge.

Ferguson, D. L., Hanreddy, A., \& Draxton, S. (2011). Giving students voice as a strategy for improving teacher practice. London Review of Education, 9(1), 55-70. doi.org/10.1080/14748460.2011.550435

Hallinger, P. \&Heck, R. H. (2010) Collaborative leadership and School improvement: understanding the impact on school capacity and student learning, School Leadership \& Management, 30(2), 95-110. DOI: 10.1080/13632431003663214

Hargreaves, D. H. (2001). A capital theory of school effectiveness and improvement. British Educational Research Journal, 27(4), 487-503. doi.org/10.1080/01411920124392

Hattie, J. A. C. (2009). Visible learning: a synthesis of over 800 meta-analyses relating to achievement. London: New York: Routledge. doi.org/10.4324/9780203887332

Hattie, J., \&Anderman, E. (Eds.) (2013), International guide to student achievement. New York: Routledge. doi.org/10.4324/9780203850398 
Hopkins, D. (2016). School improvement and system reform. In Chapman, C., Muijs, D., Reynolds, D., Sammons, P., \&Teddlie, C. (Eds.). The Routledge International Handbook of Educational Effectiveness and Improvement. London and New York: Routledge. doi.org/10.4324/9781315679488

Hopkins, D., Stringfield, S., Harris, A., Stoll, L., \& Mackay, T. (2014). School and system improvement: a narrative state-of-the-art review. School Effectiveness and School Improvement: An International Journal of Research, Policy and Practice, 25(2), 257281. doi.org/10.1080/09243453.2014.885452

HSFR (2002). Forskningsetiska principer inom humanistisk-samhällsvetenskaplig forskning. (Research ethics in humanist and social science). Stockholm: Vetenskapsrådet (in Swedish).

Håkansson, J. (2015a). Vad hände efter Hattierevolutionen? - Undervisningsrenässansen i det svenska skolutvecklingsarbetet. (What happened after the Hattie revolution - the teaching renaissance in the Swedish school improvement work (in Swedish). Paideia, 9, 52-60. ISSN 1904-9693

Håkansson, Jan (2015b). Structured teaching and classroom management - The solution for the decline of Swedish school results? Conclusions drawn from a comparative meta-synthesis of teaching and learning. Teachers and Teaching. Theory and Practice, 21(5), 584-602. http://dx.doi.org/10.1080/13540602.2014.995479

Keddie, A. (2015). Student voice and teacher accountability. Pedagogy, Culture ESociety, 23(2), 225-244. doi.org/10.1080/14681366.2014.977806

Kvale, S. \& Brinkmann, S. (2014) Den kvalitativa forskningsintervjun. (The qualitative research interview). Lund: Studentlitteratur (in Swedish).

Levin, B. (2008). How to change 5000 schools: A practical and positive approach for leading change at every level. Cambridge, MA.: Harvard Education Press.

Lodge, C. (2005). From hearing voices to engaging in dialogue: problematising student participation in school improvement. Journal of Educational Change, 6, 125-146. doi.org/10.1007/s10833-005-1299-3

Lomos, C., Hofman, R., \& Bosker, R.J. (2011). Professional Communities and Student Achievement - A Meta-Analysis. School Effectiveness and School Improvement, 22(2), 121-148. doi.org/10.1080/09243453.2010.550467

Muijs, D., Kyriakides, L., van der Werf, G., Creemers, B., Timperley, H., \& Earl, L. (2014) State of the art - teacher effectiveness and professional learning. School Effectiveness and School Improvement, 25(2), 231-256. doi.org/10.1080/09243453.2014.885451

Parr, J. M., \&Timperley, H. (2010). Multiple 'black boxes': inquiry into learning within a professional development project. ImprovingSchools, 13(2), 158-171. doi.org/10.1177/1365480210375349

Reynolds, D., Harris, A., Clarke, P., Harris, B., \& James, S. (2006). Challenging the Challenged: Developing an Improvement programme for schools facing exceptionally challenging circumstances. School Effectiveness and School Improvement, 17(4), 425-439. doi.org/10.1080/09243450600743509

Reynolds, D., Teddlie, C., Chapman, C. \& Stringfield, S. (2016). Effective school processes. In Chapman, C., Muijs, D., Reynolds, D., Sammons, P. \&Teddlie, C. (Eds.). The Routledge International Handbook of Educational Effectiveness and Improvement. London and New York: Routledge. doi.org/10.4324/9781315679488

Robinson, C., \& Taylor, C. (2007). Theorizing student voice: values and perspectives. Improving Schools, 10(1), 5-17. doi.org/10.1177/1365480207073702

Sammons, P., Davis, \& Gray (2016). Methodological and scientific properties of school effectiveness research: Exploring the underpinnings, evolution, and future directions of the field. In Chapman, C., Muijs, D., Reynolds, D., Sammons, P., 
\&Teddlie, C. (Eds.). The Routledge International HandbookofEducationalEffectiveness and Improvement. London and New York: Routledge.

doi.org/10.4324/9781315679488

Scanlon, L. (2012). ‘Why didn't they ask me?': Student perspectives on a school improvement initiative. ImprovingSchools, 15(3), 185-197. doi.org/10.1177/1365480212461824

Shulman, L. S., \& Shulman, J. H. (2004). How and what teachers learn: A shifting perspective. Journal of Curriculum Studies, 36(2), 257-271. doi.org/10.1177/0022057409189001-202

Schratz, M., \& Blossing, U. (2005). Big change question. Should pupils be able to make desicions about school change? Journal ofEducational Change, 6, 381-393. doi.org/10.1007/s10833-005-4088-0

Stoll, L., Bolam, R., McMahon, A., Wallace, M., \& Thomas, S. (2006). Professional learning communities: A review of the literature. Journal ofEducational Change, $7(4), 221-258$.

Thomson, P. (2010). Involving Children and Young People in Educational Change: Possibilities and Challenges. In Hargreaves, A., Lieberman, A., Fullan, M. \& Hopkins, D., (Eds.). Second International Handbookof Educational Change. London and New York: Springer. doi.org/10.1007/978-90-481-2660-6_45

Timperley, H. (2011). Realizing the power of professional learning. Maidenhead: Open University Press.

Timperley, H., Parr, J.M., \& Bertanees, C. (2009). Promoting professional inquiry for improved outcomes for students in New Zealand. Professional Development in Education, 35(2), 227-245. doi.org/10.1080/13674580802550094

Wennergren, A-C., \& Blossing, U. (2015). Teachers and students together in a professional learning community. Scandinavian Journal of Educational Research, 61(1), 47-59. doi.org/10.1080/00313831.2015.1066441 